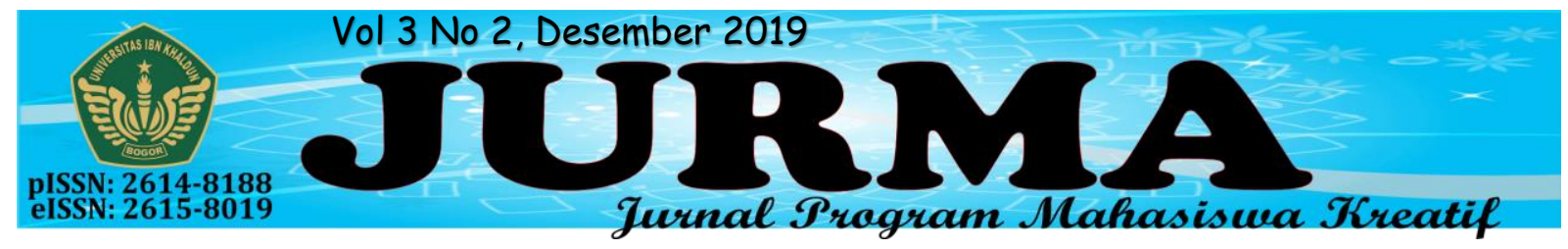

\title{
DAMPAK PERUBAHAN KONDISI GEOGRAFIS TERHADAP KEHIDUPAN SOSIAL EKONOMI MASYARAKAT DESA SAWAH BARU
}

\author{
Nur Waliya Habibatul Fathonah, Nur Kholilatusyahidah, Juwita Anggraini \\ nur.waliya@gmail.com \\ Mahasiswa Fakultas Agama Islam Universitas Ibn Khaldun
}

\begin{abstract}
ABSTRAK
Penelitian ini di latar belakangi karena banyaknya lahan pertanian yang sudah berubah menjadi sebuah perumahan dan tidak adanya lagi masyarakat desa yang mau berprofesi sebagai petani yang disebabkan oleh kehidupan sosial masyarakat yang berbeda. Dalam penulisan artikel ini kami bertujuan untuk mengetahui kehidupan perekonomian masyarakat desa Sawah Baru ditinjau dari kehidupan sosialnya. Dengan menggunakan teknik wawancara dalam pengambilan data di desa Sawah Baru kami dapat mengumpulkan informasi dengan sebaik-baiknya. Menururt data yang kami peroleh mata pencaharian di desa Sawah Baru di dominasi oleh masyarakat yang berprofesi sebagai supir angkot dan sudah jarang yang berprofesi sebagai petani walaupun potensi lahan tani di desa Sawah Baru sangat lah potensial, karena alasan ekonomi dan pendidikan masyarakat di desa Sawah Baru lebih memilih berprofesi sebagai supir angkot. Jarang sekali adanya generasi muda yang mau meneruskan profesi orang tuanya yang seorang petani karena dirasa kurang menguntungkan.
\end{abstract}

\section{Kata Kunci: Kondisi Geografis, Sosial Ekonomi, Masyarakat}

\section{PENDAHULUAN}

Ekonomi berasal dari bahasa yunani eikonomis. Eiko artinya rumah tangga, sedangkan nomis berarti aturan. Jadi eikonomis dapat diartikan aturan yang berlaku untuk memenuhi hidup dalam suatu masyarakat (Sukwiaty, dkk. 2009: 120). Dalam sebuah negara atau derah ekonomi juga sangat berperan penting dalam mengatur kehidupan masyarakat. Negara yang maju adalah negara yang dapat mengatur perekonomiannya dengan baik. Dengan dilihat dari hasil tani atau penghasilan dari para pengusaha lokal. Kenapa harus petani?, karena para petani memegang peranan penting dalam perekonomian sebuah negara. Negara dengan hasil tani yang banyak dan baik maka ia tidak perlu lagi untuk mengimpor barang dari luar negeri yang mengakibatkan produk lokal jarang diminati. Semakin jarangnya profesi petani dilingkungan masyarakat dapat dipengaruhi dari kehidupan sosial yang ada di masyarakat tersebut. Karena perekonomian sangat erat kaitannya dengan kehidupan sosial masyarakat di desa maupun kota.

$$
\text { Ranjabar (2006: }
$$
menyatakan bahwa "pembangunan nasional adalah suatu upaya melakukan transformasi atau perubahan masyarakat, yaitu transformasi dari budaya masyarakat 
agraris tradisional menjadi industri modern dan masyarakat informasi yang tetap berkepribadian indonesia". Menurut pernyataan Ranjabar tersebut dikatakan bahwa terjadinya transformasi indutri agraris pada industri modern. Perkembangan kehidupan masyarakat terutama perekonoian masyarakat desa memang akan membawa dampak baik bagi kelanhsugan hidup, tetapi kita juga tidak boleh lupa akan pentingnya profesi petani terutama jika terjadinya pembangunan diatas tanah agraris atau yang amsih sangat subur karena dpat menurunkan produk pertanian lokal sehingga harga akan semakin naik dan kita terpaksa harus mendatangkan hasil tani dari negara luar untuk memenuhi kebutuhan hidup masyarakat.

Melihat dari hal tersebut kami memutuskan untuk melakukan sebuah

\section{METODE}

Kami melakukan penelitian di desa Sawah Baru selama tiga hari yaitu pada tanggal 11, 12, dan 23 desember 2017. Kami memilih desa ini sebagai tempat penelitian karena daerahnya tidak terlalu jauh dan cocok dengan tema kami. Sebelum melakukan penelitian kami menentukan terlebih dahulu teknik penegambilan data yang akan dilakukan. Kami memilih wawancara sebagai teknik pengumpulan data kualitatif.

Wawancara adalah situasi berhadaphadapan antara pewawancara dan responden yang dimaksudkan untuk menggali informasi yang diharapkan, dan bertujuan mendapatkan data tentang responden dengan minimum bias dan maksimum efisiensi (Singh, 2002). Dalam mengumpulkan data penelitian teknik penelitian yang digunakan adalah Teknik Penelitian Kualitatif. Penelitian Kualitatif penelitian untuk melihat kehidupan sosial dan perekonomian di desa Sawah Baru. Melalui artikel ini kami berharap dapat membantu pembaca lebih memahami dan mengetahui masalah perekonomian dan kehidupan sosial di masyarakat sekitar, dan urgensi dari kelangkaan tanah agraris. Karena banyak sekali desa-desa yang telah berubah menjadi perkotaan.

\section{Tujuan}

Tujuan dari penelitian ini adalah untuk mengetahui bagaimana kehidupan perekonomian di desa Sawah Baru dan profesi dari kebanyakan penduduk disana. Dan juga untuk mengetahuai bagaimana kehidupan sosial masyarakat di desa Sawah Baru dapat mempengaruhi kegiatan masyarakat disana.

menurut Kirk \& Miller (dalam Nasution, 1988:23) pada mulanya bersumber pada pengamatan kualitatif yang dipertentangkan dengan pengamatan kuantitatif. Lalu mereka mendefinisikan bahwa metodologi kualitatif adalah tradisi tertentu dalam ilmu pengetahuan sosial yang secara fundamental bergantung pada pengamatan pada manusia dalam kaasannya sendiri dan berhubungan dengan orang-orang tersebut dalam bahasanya dan dalam pengistilahannya. Penelitian kualitataif memiliki ciri atau karakteristik yang membedakan dengan penelitian jenis lainnya.

Pengamatan kuantitatif melibatkan pengukuran tingkatan suatu ciri tertentu. Untuk menemukan sesuatu dalam pengamatan, pengamat harus mengetahui apa yang menjadi ciri sesuatu itu. Untuk itu pengamat-pengamat mulai mencatat 
atau menghitung dari satu, dua, tiga dan seterusnya. Berdasarkan pertimbangan dangkal demikian, kemudian peneliti menyatakan bahwa penelitian kuantitatif mencakup setiap penelitian yang didasarkan atas perhitungan presentase, rata-rata dan perhitungan statistik lainnya. Dengan kata lain, penelitian kauantitatif melibatkan diri pada perhitungan atau angka atau kuantitas.

Atas dasar pertimbangan itulah maka kemudian penelitian kualitataif tampaknya diartikan sebagai penelitian yang tidak mengadakan perhitungan. Pemahaman yang demikian tidak selamanya benar, karena dalam perkembangannya ada juga penelitian kualitatif yang memerlukan bantuan angka-angka seperti untuk mendeskripsikan suatu fenomena maupun gejala yang diteliti.

Menurut Strauss dan Corbin dalam Creswell, J. (1988:24), (dalam Rahmat, 2009: 2) yang dimaksud dengan penelitian kualitatif adalah jenis penelitian yang menghasilkan penemuan-penemuan yang tidak dapat diacapai dengan menggunakan prosedur-prosedur statistik atau cara-cara lain dari kuantifikasi (pengukuran). Penelitian kualitatif secara umum dapat digunakan untuk penelitian tentang kehidupan masyarakat, sejarah, tingkah laku, fungsionalisasi organisasi, aktivitas sosial dan lain-lain. Salah satu alasan menggunakan pendekatan kualitatif adalah pengalaman para peneliti dimana metode ini dapat digunakan untuk menemukan dan memahami apa yang tersembunyi dibalik fenomena yang kadangkala merupakan sesuatu yang sulit untuk dipahami secara memuaskan.

Bogdan dan Biklen, S. (1992:21-22) menjelaskan bahwa penelitian kualitatif adalah salah satu prosedur penelitian yang menghasilkan data deskriftif berupa ucapan atau tulisan dan perilaku orangorang yang diamati. Pendekatan kualitatif diharapkan mampu menghasilkan uraian yang mendalam tentang ucapan, tulisan dan perilaku yang dapat diamati dari suatu individu, kelompok, masyarakat dan organisasi tertentu dalam suatu settings konteks tertentu yang dikaji dari sudut pandang yang utuh, komprehensif dan holistik. Penelitian kualitatif bertujuan untuk mendapatkan pemahaman yang sifatnya umum terhadap kenyataan sosial dari perspektif partisipan. Pemahaman tersebut tidak ditentukan terlebih dahulu, tetapi didapat setelah melakukan analisis terhadap kenyataan sosial yang menjadi fokus penelitian. Penelitian kualitatif juga disebut dengan : Interpretive Research, Naturalistic Research, Phenomenological Research.

Selanjutnya kami menyusun pertanyaan yang akan kami tanyakan. Selanjutnya kami pergi menemui narasumber satu pada tanggal 11 desember 2017 dan kami melakukan wawancara terhadap narasumber pertama yaitu Bapak Acang seorang pendatang yang menjadi petani di desa Sawah Baru, pada hari kedua kami mendatangi narasumber yaitu Bapak Bobby selaku ketua Rw 08. 


\section{HASIL DAN PEMBAHASAN}

Wawancara sebagai cara yang dilakukan dalam pengumpulan data yang kami lakukan, wawancara menjadi langkah akhir yang kami lakukan dalam penelitian ini. Sebelum melakukan wawancara terlebih dahulu kami tentukan narasumber yang akan kami wawancarai untuk mendapatkan informasi mengenai desa Sawah Baru. Setelah itu kami mengajukan pertanyaan berkaitan dengan kehidupan masyarakat dan perekonomian di Desa Sawah Baru.

Tabel Hasil Wawancara

\begin{tabular}{|c|c|c|}
\hline Narasumber & Pertanyaan & Penjelasan Narasumber \\
\hline Pak Acang & $\begin{array}{l}\text { Bagaimana tingkat } \\
\text { pendidikan di desa } \\
\text { tersebut? }\end{array}$ & $\begin{array}{l}\text { Pendidikan di desa Sawah baru rata-rata } \\
\text { sampai tingkat SMA, namun ada juga } \\
\text { yang meneruskan hingga ke tingkat } \\
\text { perguruan tinggi, tergantung dari tingkat } \\
\text { kemampuan orang tua untuk } \\
\text { menyekolahkan anak sampai ke tingkat } \\
\text { perguruan tinggi. Serta ada pula yang } \\
\text { memutuskan langsung bekerja sebagai } \\
\text { kuli bangunan. }\end{array}$ \\
\hline Pak Unang & $\begin{array}{l}\text { Apa saja profesi yang } \\
\text { dilakukan di desa itu? }\end{array}$ & $\begin{array}{l}\text { Mayoritas profesi yang dilakukan } \\
\text { masyarakat desa Sawah Baru yaitu supir } \\
\text { angkot sekitar } 70 \% \text {, karena profesi ini } \\
\text { tidak terlalu sulit dan tidak memerlukan } \\
\text { ijazah yang diperlukan hanya keahlian } \\
\text { mengendarai kendaraan serta memiliki } \\
\text { SIM, serta untuk masyarakat yang tidak } \\
\text { bersekolah maupun hanya bersekolah } \\
\text { hingga tingkat SMP bisa berfrofesi } \\
\text { sebagai supir angkot dan sebagian } \\
\text { masyarakat ada pula yang berfrofesi } \\
\text { sebagai pengajar, dosen dan polisi. Serta } \\
\text { untuk profesi petani sebagian warga asli } \\
\text { tetapi kebanyakan warga pendatang. }\end{array}$ \\
\hline Pak Bobby & $\begin{array}{l}\text { Bagaimana kegiatan } \\
\text { keagamaan di desa itu? }\end{array}$ & $\begin{array}{l}\text { Kegiatan keagamaan yang dilakukan di } \\
\text { desa Sawah Baru biasanya maulidan dan } \\
\text { setiap bulan perayaan islam selalu } \\
\text { diadakan acara pengajian pada hari yang } \\
\text { ditentukan. Ada pula pengajian ibu-ibu } \\
\text { yang diadakan setiap hari selasa dan } \\
\text { kamis, pengajian bapak-bapak yang } \\
\text { diadakan setiap hari sabtu seletah shalat } \\
\text { magrib dan pengajian anak-anak yang } \\
\text { dilaksanakan setiap hari pada waktu sore }\end{array}$ \\
\hline
\end{tabular}




\begin{tabular}{|l|l|l|}
\hline \multirow{2}{*}{} & & hari. \\
\cline { 2 - 3 } & $\begin{array}{l}\text { Bagaimana kehidupan } \\
\text { masyarakat di desa } \\
\text { Sawah Baru? }\end{array}$ & $\begin{array}{l}\text { Kehidupan masyarakat di desa ini } \\
\text { masyarakatnya gotong royong, terlihat } \\
\text { dari kegiatan yang dilakukan dua } \\
\text { minggu sekali yaitu kerja bakti } \\
\text { pembangunan masjid dan pengerjaan } \\
\text { jalan. }\end{array}$ \\
\hline Pak Acang & $\begin{array}{l}\text { Apakah di desa ini } \\
\text { masih melakukan } \\
\text { kegiatan pertanian? }\end{array}$ & $\begin{array}{l}\text { Kegiatan pertanian di desa ini masih } \\
\text { dilakukan oleh para petani setiap } \\
\text { paginya hingga menjelang dzuhur. } \\
\text { Namun kebanyakan petani yang bertani } \\
\text { di desa ini merupakan masyarakat } \\
\text { pendatang yang berasal dari desa lain. }\end{array}$ \\
\hline
\end{tabular}

Berdasarkan hsil penelitian diatas desa sawah baru merupakan desa yang telah mengalami teransformasi dari indusrti tradisional pada industri modern atau bisa kita sebut sebagai desa maju, karena kebanyakan penduduknya sudah tidak berprofesi sebagai petani. Menurut data yang kami dapat. Mayoritas masyarakat disana hampir $70 \%$ nya bekerja sebagai supir angkot. Menurut narasumber kami profesi ini dipilih karena persyaratannya yang tidak terlalu sulit dibandingkan dengan pekerjaan yang lain karena untuk menjadi supir angkot tidak memerlukan ijazah yang dibutuhkan hanyalah kemampuan mengemudi dan memiliki SIM.

Selain alasan diatas ada faktor-faktor lain yang menyebabkan warga desa sawah baru tidak lagi meminati pekerjaan sebagai petani, karena :

\section{KESIMPULAN}

Masyarakat desa sawah baru lebih meminati pekerjaan sebagai supir angkot karena perubahan yang terjadi di desa itu. Sedangkan profesi sebagai supir angkot tidak terlalu sulit karena tidak memerlukan
1. Tidak adanya modal untuk melakukan kegiatan petani terutama untuk menanam padi

2. Tanah untuk pertanian tidak terlalu luas

3. Jumlah hasil panen tidak sesuai dengan modal awal, sehingga lebih besar modal daripada hasil

4. Masyarakat lebih suka menyewakan tanahnya daripada bertani langsung.

5. Banyak warga yang memilih menjual tanah pertaniannya karena kesulitan ekonomi

Sedangkan untuk profesi yang lainnya seperti, guru, wirausaha, dan yang lainnya dimiliki oleh para pendatang. Karena sudah banyak sekali pendatang yang tinggal dan hidup disana. Dan para pendatang pula yang memiliki tanah pertanian yang ada di desa sawah baru.

ijazah, hanya membutuhkan kemampuan menegmudi dan memeiliki SIM. Pertanian merupakan profesi yang sulit dibandingkan supir angkot karena seorang petani harus memiliki pengetahuan tentang pertanian, 
harus memiliki lahan, harus memiliki modal yang cukup, sedangkan hasil pertanian tidak dapat diprediksi dan kebanyakan tidak sesuai dengan modal

\section{DAFTAR PUSTAKA}

Bogdan, R., dan Biklen, S. 1992. Qualitative Research for Education. Bosttom, MA: Allyn and Bacon.

Nasution, S. 2003. Metode Penelitian Naturaliatik Kualitatif. Bandung: Tarsito. awal. Juga karena sudah banyaknya jalan besar yang dibangun disana dan juga faktor kurangnya minat kaum muda disana terhadap pertanian.

Rahmat, Pupu Saeful. 2009. Penelitian Kualitatif. EQUILIBRIUM, Vol.5, No.9.

Ranjabar, Jacobus. 2006. Sistem Sosial Budaya Indonesia (Suatu Pengantar). Bogor: Ghalia Indonesia. 